\title{
Editorial
}

\section{The Contribution of Self-Involvement and Social Rejection to Social Change Perception}

\author{
Juneman Abraham \\ Psychology Department, Faculty of Humanities \\ Bina Nusantara University
}

\author{
Bagus Takwin \\ Faculty of Psychology \\ Universitas Indonesia
}

Eibach, Libby, and Gilovich's (2003) experimental research suggested that people with less self-change awareness will perceive that their social worlds change more than do those who are more aware that they themselves are changing. This present review, based on two other studies, serves as a further research recommendation to expand their thesis. Social cognition experiments conducted by Cloutier and Macrae (2008) as well as by Hess and Pickett (2010) using the social memory paradigm indicated that if a person experiences: (1) personal disengagement (self-univolvement, i.e. his/her experience is chosen by others); and (2) social rejection, then he/she will be less aware of him/herself, and will remember more (or is more aware of) information regarding other people (others > self). Reversely, a person with: (1) self-involvement (i.e. selects his/her own experience); and (2) social acceptance experience, will be more aware of him/herself than of others (self > others) and will perceive the social world to change less. Based on those findings, the authors hypothesize that self-involvement and social rejection-as variables that influence the awareness of self (changes)-influence one's perception of social changes. Some applications related to colonial mentality, as well as Bitcoin and blockchain technology, are presented as illustrations to elaborate the conjecture.

Keywords: social change, self-change, awareness, self-involvement, social rejection, philosophical psychology, social memory

Penelitian eksperimental Eibach, Libby, dan Gilovich (2003) menunjukkan bahwa orang dengan ketidaksadaran perubahan diri akan mempersepsi dunia sosialnya berubah lebih banyak daripada orang yang menyadari bahwa dirinya berubah. Kontribusi kajian kali ini adalah sebagai rekomendasi penelitian lanjutan yang memperluas tesis mereka. Eksperimen kognisi sosial yang diselenggarakan oleh Cloutier dan Macrae (2008) serta Hess dan Pickett (2010) dengan menggunakan paradigma ingatan sosial menunjukkan bahwa apabila orang mengalami: (1) ketidakterlibatan diri (pengalamannya dipilihkan oleh orang lain); dan (2) pengalaman penolakan sosial, maka ia akan kurang menyadari dirinya, dan lebih mengingat atau menyadari informasi yang terkait dengan orang lain (yang lain $>$ diri). Demikian pula terjadi pada arah sebaliknya, orang dengan: (1) keterlibatan diri (memilih pengalamannya sendiri); dan (2) pengalaman penerimaan sosial akan lebih menyadari dirinya daripada orang lain (diri > yang lain), dan akan mempersepsikan dunia sosial berubah lebih sedikit. Berbasiskan temuantemuan tersebut, penulis berhipotesis bahwa keterlibatan diri dan penolakan sosial-sebagai variabel-variabel yang mempengaruhi kesadaran tentang (perubahan) diri-mempengaruhi persepsi seseorang terhadap perubahan sosial. Sejumlah penerapan pengetahuan terkait dengan mentalitas kolonial serta Bitcoin dan teknologi blockchain dijadikan ilustrasi untuk memperjelas dugaan tersebut.

Kata kunci: perubahan sosial, perubahan diri, kesadaran, keterlibatan diri, penolakan sosial, psikologi filosofis, ingatan sosial

The authors gratefully acknowledge the weighty discussion on Bitcoin studies supporting the proposition of this present review, from Mr. Wing Ispurwanto, a faculty member of Psychology Department, Bina Nusantara University.

Correspondence concerning this article should be addressed to Juneman Abraham, Psychology Department, Faculty of Humanities, Bina Nusantara University, Jalan Kemanggisan Ilir III No. 45, Palmerah, DKI Jakarta 11480 Email: juneman@ binus.ac.id 
Various social psychology studies suggested that social perception is prone to bias (e.g., Bargh \& Pietromonaco, 1982; Moskowitz, 2005; Nisbett \& Wilson, 1977). Eibach and Libby (2009) found that when a person becomes a parent, that person sees the world as a more dangerous place, but fails to recognize that his/her personal/self-change is the thing responsible for that perception. Once parents start to have children, their children's safety is at stake, and this vulnerability affects perceptions of hazards in the environment. People also fail to be aware that their view which sees a current social decline is influenced by their physical and mental condition which experiences changes, known as aging. As a result, they feel they experience more frustration concerning the world's changes. Juneman and Takwin (2011) found that the lower personal change awareness college students have, the more they perceive that their campus world changes a lot.

Eibach, Libby, and Gilovich (2003) further found that even though one is made aware of his/her changes, attribution errors in the number of social changes will happen if one does not possess enough cognitive resources, such as a condition caused by cognitive overload. One needs to reflect and exercise cognitive effort to recognize that his/her own personal changes have changed his/her perception of social world changes. Cognitive overload brings about attenuation effects on personal change awareness. Following the logic of their thesis, this present review hypothesizes that every variable which can bring about attenuation of personal awareness can serve as a psychological variable which causes people to make exaggerated judgments on world or social changes. This review inspires future empirical researchers to find and confirm the roles of the variables.

Previous studies showed that self-involvement improves information memorability regarding the self (objects-associated-with-self > objects-associated-withother) (e.g., Macrae, Moran, Heatherton, Banfield, \& Kelley, 2004). It is known as the self-reference effect/ SRE in memory (Symons \& Johnson, 1997), which is caused by a state experienced by the people who think that they are the actors or authors of their own behaviors. Cloutier and Macrae (2008) sharpened those findings. They found out the kind of self-involvement which improves information memorability and accessibility is self-involvement which is moderated by the act of choosing. The experiment they conducted showed that, compared to participants whose information was selected by a partner (others) or was material pre-assigned by experimenters (others), parti- cipants who played active roles in selecting related information (selecting $>$ assigned) remembered more. People who selected their own experience (volitional, self-involved, people as agents) are more self-aware than those whose experience is not selected by themselves (assigned to self, e.g. undergo given experience, do/experience particular things because they are required or forced to do so). In other words, people who experience self-disengagement (uninvolvement) will focus their attention more on others or the social world (other > self).

Twenge, Catanese, and Baumeister's (2003) study found that people who are socially rejected will avoid personal awareness and will think more of what might be wrong about them-which has caused others to reject them. Regarding this, the Gestalt psychological concept states that social rejection causes the sufferers to feel that they change from figures into backgrounds because their condition is seen as no longer ideal/positive; it causes people to be less self-focused (Snow, Duval, \& Sylvia, 2004). This is because people who are socially rejected will experience acute distress, which they need to develop a defensive strategy to protect themselves from distress. Distress is caused by a negative self-concept as a result of social rejection. Therefore, people need to restore their positive self-concept. The most common way to do this is by self-forgetting (so that they do not need to face the memory of weaknesses and failure in the eyes of society, which have happened), and at the same time improve their attention to the social world (so that they can be helped to shape and maintain social relationships, which can satisfy their willingness to stay connected to the social world). Hess and Pickett (2010) found similar results, that people who are socially rejected demonstrate better memory of other-related social behavior, but a bad memory of self-related social behavior, when compared with people who are socially accepted. This is because social rejection triggers responses in the form of self-defense strategies aimed to restore and maintain social relationships. It could be concluded that social rejection triggers the act of disengagement from the self and more attention being given to others or to the social world, similarly to the effects of self-uninvolvement.

This present review hypothesizes that self-uninvolvement and social rejection influence one's perception of social changes in positive directions.

\section{Plausible Operationalization}

In order empirically to test the hypothesis among 
university students, this review suggests predictive correlational design with self-involvement and social rejection as predictors (independent variables), and perception of social change as a criterion (dependent variable).

Perception of a social change scale could be developed based on the perspectives of higher education parties (Juneman \& Takwin, 2011), such as: (1) Lecturers, e.g., "So far, the campus world has experienced changes in lecturer quality"; (2) Students, e.g., "The campus world has experienced many changes regarding between-student relationships"; (3) Staff, e.g., "The campus world has experienced many changes in its staff behavior"; and (4) The university, e.g., "The campus world has experienced many changes in terms of facilities." The scale would consist of 10 statements, with responses ranging from "Strongly Disagree" (scored 1) to "Strongly Agree" (scored 5).

The Modified Involvement Scale (MIS) by Kyle, Absher, Norman, Hammitt, and Jodice (2007) could be used to measure self-involvement. The 15-item scale's dimensions, making: (1) social bonding, e.g., "Participating in the campus world gives me an opportunity to be with my friends"; (2) identity affirmation, e.g., "When I participate in the campus world, I can really be myself"; (3) identity expression, e.g., "Participating in the campus world explains many things about who I am"; (4) attraction, e.g., "The campus world is one of the most exciting things in my life"; and (5) centrality, such as, "To replace the campus activities I like with other activities, I would need to think it over deeply." The response options would range from "Strongly Disagree" (scored 1) to "Strongly Agree" (scored 5).

The social rejection scale could be adapted and developed, based on construct aspects in The Rejection Sensitivity Questionnaire (RSQ) by Downey and Feldman (1996). The RSQ consists of 18 situations with two dimensions, making a total of 36 statements. The 18 situations describe things with which college students sometimes ask others to help. The first dimension is anxious expectations of rejection, with the responses ranging from "Not Very Worrying/Not Very Concerned About" (scored 1) to "Very Worrying/Very Concerned About" (scored 6). The second dimension is self-expectation of the possibility of acceptance by significant others with the responses ranging from "Very Unlikely" (scored 1) to "Very Likely" (scored 6). Examples of the RSQ items are given in Table 1. Refer to http://www.midss.org/rsq rs-personal-8-item-and-18item (Downey \& Feldman, 1996) for RSQ scoring. Some situations given in the scale should be adapted to Indonesian situations to get the same psychological effect, or be similar to the situations cited in the source instrument. Some of these could be adapted from: (a) a situation such as: "You ask your boyfriend/girlfriend to move in with you" adapted to become, "You ask your friend to build a new business with you"; (b) a situation such as: "After graduation you can't find a job and you ask your parents if you can live at home for a while", adapted to "After graduation, you ask your parents if it is possible for you to become engaged to your boy/girlfriend even though you do not have a job"; and (c) a situation such as: "You ask a friend to go on vacation with you over Spring Break" adapted to "You ask a friend to go with you over a religious holiday."

The data can be analyzed using multiple linear regression analysis, with self-involvement and social rejection as predictors, and perception of social change as the criterion. It is expected that the social change perception of those who experienced self-disengagement would experience more overestimation bias than that of those who experienced self-involvement, and that the perception of social change of those who experienced social rejection would experience more overestimation bias than that of those who experienced social acceptance.

The results of the correlational study could be triangulated with a true experimental study with $2 \times 2$ factorial design (see Table 2) with self-involvement (involved/selected vs. not involved/selected) and social rejection (accepted vs. rejected) as independent variables (causes) and perception of social change as the dependent variable (effect) to confirm causal relationship. The Cyberball-tossing game (Williams, Cheung, \& Choi, 2000; Zadro, Williams, \& Richardson, 2004) could be used as the assessment instrument. Self-involvement is operationalized as "the experience to choose the number of players and opponents in the Cyberball game which involves the campus world community", whereas self-uninvolvement serves as "the experience of having others choose the number of players and opponents in the Cyberball game involving the campus world community." Social rejection is operationalized as "the rejected experience in the Cyberball game involving the campus world community", while social acceptance serves as "acceptance experience in the Cyberball game involving the campus world community".

The suggested procedure is as follows: Experimenters go into a class where participants are gathered and explained that the participants will be involved 
Table 1

Example of RSQ Items (Downey \& Feldman, 1996) Situation Item

You ask someone in class if you can borrow his/ 1. How concerned or anxious would you be over whether or not the her notes. person would want to lend you his/her notes?

2. I would expect that the person would willingly give me his/her notes.

After class, you tell your professor that you have been having some trouble with a section of the course and ask if he/she can give you some extra help.
1. How concerned or anxious would you be over whether or not your professor would want to help you out?

2. I would expect that my professor would want to help me out.

Table 2

Suggested Experimental Design

\begin{tabular}{|c|c|c|c|}
\hline & & \multicolumn{2}{|c|}{ Self-Involvement } \\
\hline & & Selecting Experience & Assigned Experience \\
\hline \multirow{2}{*}{ Social Rejection } & Being accepted experience & $\begin{array}{c}\mathrm{C} 1 \\
\text { Perception of social change }\end{array}$ & $\begin{array}{c}\text { C3 } \\
\text { Perception of social change }\end{array}$ \\
\hline & Being rejected experience & $\begin{array}{c}\mathrm{C} 2 \\
\text { Perception of social change }\end{array}$ & $\begin{array}{c}\text { C4 } \\
\text { Perception of social change }\end{array}$ \\
\hline
\end{tabular}

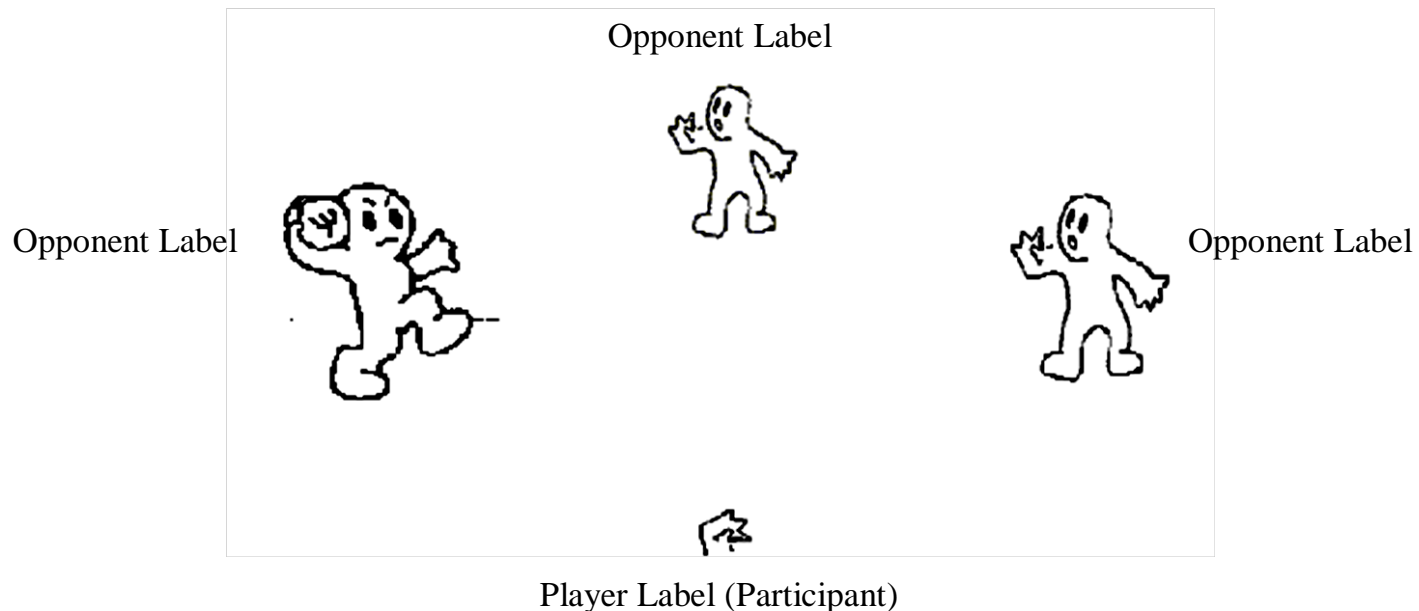

Figure 1. Illustration of player and opponents' position in the experimental game

(Williams et al., 2000; Zadro et al., 2004)

in a research project, and ask for their agreement. The experimenters offer lotteries (tickets) with $\mathrm{C} 1$ to $\mathrm{C} 4$ code. The participants are asked to take a ticket at random. After that, the participants are asked to execute a program file on their computers. The experimenters explain that the participants will play the Cyberball-tossing game with their "partners" in a parallel laboratory at the same time (synchronously, in real-time) using the internet. Experimenters then display a list of "students" (attendance list) in the parallel laboratory on a slide at the front of the class [This is one deception part of the experiment]. In the game program, the participants are asked to fill in an online form, based on their preferences. The 
data to be filled in are: (a) a nickname; (b) the number of players (three or four people) [the total number of players includes both the participants and their opponents]; (c) lottery number $(\mathrm{C} 1 / \mathrm{C} 2$ / C3 / C4); and (d) the names of the second and third players (if the total number of player is three) or the names of the second, third, and fourth players (if the total number of players chosen is four), who are in the parallel laboratory. The names of the opponents may be freely chosen by participants from the attendance list on the slide. As a deception procedure, participants are told that they are going to participate in research testing a mental visualization effect. To help them train their mental visualization skills, they are to play an online Cyberball-tossing game using the Internet Explorer browser. They are told that their performance in tossing the ball is not important because the game is a means for them to practice their mental visualization skills. They are asked to imagine themselves, their opponents, and the game situation. They are asked to freely imagine such things as how the other players perform, what kind of people the other players are, where the game is being played, and how the weather conditions are (warm, cold, rainy, or maybe sunny). They are asked to create a complete mental image of what is happening as if they are playing the game in real life. Participants' position is always in the middle-lower position and the participants are asked to toss a ball to another opponent as soon as they receive it (see Figure 1). The game is displayed using animation, wherein player icons toss a ball to each other. Each session of the game consists of 30 throws (game duration is around 4-5 minutes).

Around five seconds after the game starts, the experimenter tells the players that if the name of the college students chosen from parallel laboratory did not emerge, or there is more than one player who chooses the same name, participants will play against the experimenter's team who are monitoring from $a$ different place (deception). Soon after this explanation, the experimenter asks, "Is there any one amongst you whose requests have not been met? This would mean that the number of opponents and/or the name of the opponents displayed in the game does not correspond to the players' requests, as filled in on your forms." Some participants will raise their hands. The experimenters' assistant will quickly respond, saying, "It is OK. There are some students in this class whose requests or choices have not been granted. Those whose requests have not been granted will play against our team which is monitoring from a different place." Those whose requests were not granted will see $A$ (random number) or B(random number), rather than the names of the opponents previously selected from the attendance list for the parallel laboratory, on the displayed list of opponents' names.

Initially, the experimenter set the game based on the lottery number randomly allocated to the participants (C1 / C2 / C3 / C4). The participants actually play with the "program" set by the experimenters, but they are told that they will play using an internet connection with other "real players". This is the deception in the research. There are four game conditions randomized for the participants, based on the conditions in Table 2. For example, Participant $\mathrm{C} 1$ will play the game set in such a way that he/she receives: (1) a "selecting" experience (the number and the names of the opponents he/she requested were granted/appeared in the game display on the computer screen); and (2) "accepted" experience (participants randomly received a ball for a quarter of the total throws if there were four total players, or a third if the total players were three). Participants with C4 number got: (1) "rejected" experience (participants randomly accepted a ball twice at the most from the opponents if the total players were three, or three at the most if the total players were four); and (2) an "assigned" experience (the number and the names of opponents he/she requested were not granted. In this case, there will be four players, including the participants whose names are displayed on the computer screen. Therefore, there will be three opponents, and the names of the opponents will be different from the participant's requests). This experience is the source of the experimental manipulation.

At the end of the game, Internet Explorer will display a 'thank you' note and a request for the participants to await the next instructions. After this, the experimenter might ask the participants to fill in the three post-experiment scales and might conduct a debriefing (a more elaborate explanation of the original purpose of the research).

The first post-experiment scale is a manipulation check scale adapted from The Modified Involvement Scale (MIS) (Kyle et al., 2007) measuring the participants' involvement. The dimensions are: (1) attraction, for example, "After knowing whether or not the names of the opponents I requested was granted, the game became interesting for me"; (2) centrality, such as, "The number and names of the opponents displayed has strengthened my willingness to play the game"; (3) social bonding, for example, "I felt close to my opponents, regardless of how the game turned out"; (4) identity affirmation, such as, "When 
participating in the game, I could be myself"; and (5) identity expression, for example, "People will know what sort of gamer I am by noting my considerations in choosing the number and opponents." The response options would range from "Strongly Disagree" (scored 1) to Strongly Agree" (scored 5).

The second post-experiment scale is a manipulation check scale, with The Social Rejection Questionnaire as a function of the Cyberball-tossing game (Williams et al., 2000; Zadro et al., 2004). The dimensions are: (1) Intensity of ostracism, such as, "I was: Accepted...... Rejected"; (2) Degree of threat to needs (belonging, control, self-esteem, meaningful existence), for example, "I felt like an 'outsider' throughout the game", "I felt that I could toss the ball as often as I wanted" (unfavorable item), "I felt that other players failed to perceive me as a valuable and nice person"; "(3) Mood, such as "I am: Sad....... Happy" (unfavorable item); and (4) Ancillary variables, for example, "I was angry throughout the game". The response options for Dimensions (2) and (4) might range from "Strongly Disagree" (scored 1) to "Strongly Agree" (scored 6).

The responses of perception of social change scale might range from "Strongly Disagree" (scored 1) to "Strongly Agree" (scored 6), and are developed based on perceptions of higher education position holders (Juneman \& Takwin, 2011), these being: (1) Lecturers; (2) Students; (3) Staff; and (4) University.

When tested using an independent t-test, there should be significant differences in the total score of self-involvement between the groups set to choose their own experiences $(\mathrm{C} 1, \mathrm{C} 2)$ and the groups allocated assigned experiences $(\mathrm{C} 3, \mathrm{C} 4)\left(M_{\text {selecting }}>\right.$ $M_{\text {assigned }}$ : indicating self-involvement) as well as between the groups set to be accepted socially $(\mathrm{C} 1, \mathrm{C} 3)$ and the groups set to be rejected by others $(\mathrm{C} 2, \mathrm{C} 4)$ ( $M_{\text {accepted }}<M_{\text {rejected }}$ : indicating social rejection). ANOVA 2 x 2 between-participants should be conducted to investigate whether there are main effects of: (1) self-involvement; and (2) social rejection. If significant, a post hoc analysis can be done to show: (1) whether the participants who experienced selfinvolvement in the game, with the number of opponents they selected/requested being granted, perceived that the world changed less for them than did those who did not feel involved in the game; as well as (2) whether the participants experiencing social rejection throughout the game perceived that the world changed more than did those who experienced social acceptance. Also, should be conducted as to whether variance analysis shows interaction effect(s) be- tween self-involvement and social rejection regarding social change perception. Finally, the researchers might investigate the degree of the effect size of self-involvement and social rejection variables, based on Cohen's (1988) criteria.

\section{Supports from Other Studies on Social Rejection Effects}

There are other research findings which might support this present review and its derived hypotheses. Social rejection takes place in colonialism, as stated by the title of Coates and Powell (1989)'s book, The Modern North: People, Politics and The Rejection of Colonialism. David and Okazaki (2006) found the effect of colonialism among Filipino Americans. This effect is called "the colonial mentality", which is characterized by ethnic and cultural inferiority involving "uncritical rejection of anything Filipino and ... uncritical preference of anything American" (David \& Okazaki, 2006, p. 241). Many Filipino Americans use skin whitening products, want to have a white complexion, discriminate against non-white people, have a superior perception of white people and Western culture, and prefer anything that is white or from the West (Bergano \& Bergano-Kinney, 1997; Revilla, 1997). Interestingly, Okazaki, David, and Abelmann (2008) stated that, based on David and Okazaki's (2006) study, behaviors and emotions associated with colonial mentality can be detected at a subconscious level. They found that the stimuli related to the Filipino examples have been associated with the concept of inferiority, undesirability, and unpleasantness. Meanwhile, the stimuli related to Americans have been associated with the concept of superiority, desirability, and pleasantness. The conclusion of their study is that cognition in line with colonial mentality can occur automatically and subconsciously. The findings are concrete examples of the application of this present review's conjecture, that is, how social rejection (in this case: colonialism) influences perception of social world changes (things related to the West are perceived to be superior, more pleasant, and desirable), even at the level of individual's subconscious.

Another piece of research related to social rejection is Goodwin, Williams, and Carter-Sowell's (2010) study. They asked participants to play the Cyberballtossing game with manipulations pertaining to feelings of being rejected, accepted, or highly accepted. They employed manipulation so that the participants believed that their opponents in the game were the 
members of 'in-group' or 'out-group' races. Their study suggested that socially rejected participants (compared to the accepted) attributed social rejection more to racial prejudice. Among whites, this occurred more when their opponents were of an 'outgroup' race (dark-skinned). On the other hand, the effect among African Americans did not depend on whether or not their opponents were from an 'outgroup' or an 'in-group'. In addition, the research findings indicated that after giving attribution, participants felt less stress (caused by social rejection). Participants' stress became lower because they felt they were able to explain why they had been rejected, i.e. their opponents were prejudiced against them. This attribution had also taken the form of "ruminative substance" leading participants to focus on their experience of being rejected which they had had no time to reflect upon for themselves. The Goodwin et al.'s (2010) research findings can be explained by this present review's conjecture. Social rejection makes people who experience it avoid reflective consciousness of their self-changes which have been threatened by the need for belonging, control, self-esteem, and a meaningful existence. Participants did not realize that their self-changes had made them focus on others. Other people are seen to have more prejudice and to be more discriminative.

The practical implication would be for an advertising strategy which "rejects" potential consumers. Social rejection could be implemented through a message suggesting that if a potential consumer does not use the advertised product, he/she will be "marginalized", excluded from the community, from community activity, etc. Such a feeling of rejection might heighten the consumer's perception of the social environment's behavioral changes. It might well seem that the situation is more positive and nicer (than the reality) he/she were to use the advertised products. On the other hand, the behavior of other people might seem to be more negative if they do not use the product. What really causes the effect here is whether or not he/she can fulfill needs for a sense of belonging, for control, self-esteem, and a meaningful existence. Another example might be, for example, a teenager whose love is rejected (unrequited love) by the one whom he/she really loves, or a writer who is rejected by a publisher who was expected to publish his/her work. Such a person may see the world as having changed, being no longer friendly, or becoming crueler. These people can be helped to realize that the social rejection they experience has decreased their awareness of their self-changes. They are more prone to experience a negative self-concept or a fall in their self-esteem owing to rejection, and they become more sensitive to every "rejection-related" behavior cue around them. This will trigger chronic pressure (stress) if the people fail to recognize that it is not the world which changes into a place less friendly or crueler to them, but it is their sensitivity which increases, as a form of self-protection from repeated rejection experiences.

\section{Supports from Bitcoin Studies on Self- Involvement Effects}

Legault (2017) explained that the acceptance of considerable social change in the current economic climate, i.e. the presence of Bitcoin (along with the Blockchain technology it carries), which can be used for both transactions and as a trade commodity, depends on the extent to which one's involvement in one's own "internal-evolutionary" experience. This present review hypothesizes that the higher one's self-involvement towards one's own experience, this being compatible with the characteristics of Bitcoin and blockchain technology, the lower the magnitude of culture shock one experiences, related to the emergence of the virtual currency. This is in accordance with the statement of Kurt and Gök (2015, p. 5, 2627) that "technology ... increases the possibility of ... disappearance of the culture importance .... As the technology still evolves, our culture will keep on changing ....Getting more information on culture and sharing would prepare that person to be aware of the culture shock."

The experience referred to by Legault (2017) is a "relational template"-relevant experience. Associated with previous discussions about the effects of selfinvolvement and perceptions of social change, it appears that people who consider Bitcoin and blockchain as small social changes are the ones who have strongly-lived relational templates in their pasts. They might be people who have experienced: (1) a secure attachment during the first six years of life; (2) a decentralized experience, such as by undergoing institutional daycare where, during their childhood, they had experience of trustworthy authorities other than their parents; (3) a blended family, wherein they have "more attachment nodes" with the presence of step-families; and (4) a secure peerattachment. This four-dimensional experience of relational templates can enhance one's self-involvement with the decentralization experience, so that one would not be shocked by disruptive technological developments in the 
economic field, leading to the decentralization of financial authorities which no longer rely on the central bank, but on the "shared public ledger" (blockchain technology).

Wu (2017, par. 8) explained further, "Many of us are fascinated with new technologies, such as artificial intelligence, augmented reality, virtual reality, and robotics, because science fiction story-tellers have been feeding us for decades with glorious and terrifying visions of Utopian or Apocalyptic outcomes. Our emotions are prepared for either or both directions". The narrative is an access to self-involvement/ engagement, at least virtually, through the mediation of preparedness. In fact, the narratives can construct the self, promote one's roles and goals as actors and agents, as well as influence one's future (Blair, 2016; McAdams, Josselson, \& Lieblich, 2006). Thus, the narrative helps in driving acceptance, adoption, and appropriation (see also, Prayoga \& Abraham, 2017) of technology, by shrinking perceptions about the size of social changes. In everyday life, a surprise is considered to be a change on a large scale, because the people who are given a surprise do not experience self-involvement in designing the surprise. It is arguable that participation in technological change can be achieved through participation in discussing or modifying the narrative of the change, so it does not come as a shock.

An important point is how to ensure the narrative does not cause a person to experience illusionary bias, denying the facts, and that the self-fulfilling prophecy produced bring about a higher quality of life (Wu, 2017). In addition, a decrease in self-engagement can be caused by absorption of social mentality. Social mentality (synonymous with the concept of a social mind, social intelligence) is "many individual minds in interaction, so playing upon one another that they simultaneously feel the same sensation or emotion, arriving at one judgment and perhaps act in concert" (Giddings, 1896, p. 134). Social mentality, despite having a locus in the individuals' mind, is clearly a social creation, takes place through a communication process, is emotive-evaluative, and always persuades a person to reformulate the self (Gilbert, 2016). One's self-consciousness does require the connectivity and recognition of other's self-consciousness but, in some facets, can "fall on" social mentality (Williams, 2000), especially those forms of social mentality which move further into herd or mob mentality (Price, 2013) [assigned experience] that has negative connotations (i.e. primitive, destructive, and selfish). Thus, the necessary type of self- involvement to produce a healthy social perception is an engagement which takes into account the common good, promotes caring (e.g. towards environment; Abraham, Pane, \& Chairiyani, 2015), and responsibility of the self, can negotiate with, rather than be depressed by, others, or other powerful forces (cf. Abraham, Takwin, \& Suleeman, 2017), and which demotes the negative effects of deindividuation.

\section{Concluding Remarks}

This present review concludes that self-involvement and social rejection have influences on the perception of social changes. Compared to those who have self-involvement or social acceptance experience, people with self-disengagement/uninvolvement or socially rejected experience, will have a perception of world changes of a bigger magnitude. This review suggests new theoretical propositions in understanding social cognition, with social change as the object. The findings of this review can be used for education, counselling, and psychotherapy for those who are frustrated with the environment because they are unaware of their self-changes produced by the two predictor variables.

The findings of this review could be used by politicians, economists, social institution consultants, and cultural experts to create an impression for stakeholders or constituents that the changes they create in the world are big changes, even seeming to be bigger than the real changes. This can be done by managing the level of self-involvement and rejected feelings of the subjects, guided by ethical considerations. Further studies are suggested to follow up this review by investigating change direction. This review focuses on the quantitative aspect of social changes (perceived to be more or less by participants, suggested to be measured by the statistical mean), but it has not delved deeply into the direction of social changes (perceived to be more positive/better or more negative/worse by participants). Empirical research on factors influencing the qualitative aspect of social change will be more interesting, and may expand the conjecture of this review.

\section{References}

Abraham, J., Pane, M. M., \& Chairiyani, R. P. (2015). An investigation on cynicism and environmental self-efficacy as predictors of pro-environmental behavior. Psychology, 6, 234-242. https://doi.org/10. 
4236/psych.2015.63023

Abraham, J., Takwin, B., \& Suleeman, J. (2017). Counterfeit self: A confirmatory factor analysis among Indonesians. Kasetsart Journal of Social Sciences. Advance online publication. https://doi. org/10.1016/j.kjss.2017.07.011

Bargh, J. A., \& Pietromonaco, P. (1982). Automatic information processing and social perceptions: The influence of trait information presented outside of conscious awareness on impression formation. Journal of Personality and Social Psychology, 43(3), 437-444. https://doi.org/10.1037/0022-3514.43.3. 437

Bergano, A. L., \& Bergano-Kinney, B. L. (1997). Images, roles, and expectations of Filipino Americans by Filipino Americans. In M. P. P. Root (Ed.), Filipino Americans: Transformation and identity (pp. 198-207). Thousand Oaks, CA: Sage. https:// doi.org/10.4135/9781452243177.n13

Blair, M. (2016, July 21). Why every leader should understand narrative psychology. PsychologyToday. Retrieved from https://www.psychologytoday.com/ us/blog/resilientleadership/201607/why-every-lea der-should-understand-narrative-psychology

Cloutier, J., \& Macrae, C. N. (2008). The feeling of choosing: Self-involvement and the cognitive status of things past. Consciousness and Cognition, 17(1), 125-135. https://doi.org/10.1016/j.concog. 2007.05.010

Coates, K., \& Powell, J. (1989). The modern North: People, politics and the rejection of colonialism. Toronto, Canada: James Lorimer.

Cohen, J. (1988). Statistical power analysis for the behavioral sciences (2nd ed.). Lawrence Erlbaum Associates.

David, E. J. R., \& Okazaki, S. (2006). The Colonial Mentality Scale (CMS) for Filipino Americans: Scale construction and psychological implications. Journal of Counseling Psychology, 53, 241-252. https://doi.org/10.1037/0022-0167.53.2.241

Downey, G., \& Feldman, S. I. (1996). Implications of rejection sensitivity for intimate relationships. Journal of Personality and Social Psychology, 70 (6), 1327-1343. https://doi.org/10.1037/0022-351 4.70.6.1327

Eibach, R. P., \& Libby, L. K. (2009). Ideology of the good old days: Exaggerated perceptions of moral decline and conservative politics. In J. T. Jost, A. C. Kay, \& H. Thorisdottir (Eds.), Social and psychological bases of ideology and system justification. New York, NY: Oxford University Press. https://doi.org/10.1093/acprof:oso/978019532091 6.003.016

Eibach, R. P., Libby, L. K., \& Gilovich, T. D. (2003). When change in the self is mistaken for change in the world. Journal of Personality and Social Psychology, 84(5), 917-931. https://doi.org/10.1037/ 0022-3514.84.5.917

Giddings, F. H. (1896). The principles of sociology. New York: Macmillan \& Co. (Columbia Univ. Press).

Gilbert, P. (2016). Human nature and suffering. London, UK: Routledge.

Goodwin, S. A., Williams, K. D., \& Carter-Sowell, A. R. (2010). The psychological sting of stigma: The costs of attributing ostracism to racism. Journal of Experimental Social Psychology, 46(4), 612618. https://doi.org/10.1016/j.jesp.2010.02.002

Hess, Y. D., \& Pickett, C. L. (2010). Social rejection and self- versus other-awareness. Journal of Experimental Social Psychology, 46(2), 453-456. https:// doi.org/10.1016/j.jesp.2009.12.004

Juneman, J., \& Takwin, B. (2011). Kesadaran perubahan diri dan persepsi terhadap perubahan sosial pada mahasiswa. Jurnal Ilmiah Psikologi, 5(1), 105114. Retrieved from http://www.academia.edu/18 40566/Kesadaran_Perubahan_Diri_dan_Persepsi_ Terhadap_Perubahan_Sosial_Pada_Mahasiswa

Kurt, I., \& Gök, H. (2015). Impact of technology on the perceptions of culture shock. Mevlana International Journal of Moral and Values Education (MIJMVE), 2(2), 21-28.

Kyle, G. T., Absher, J. D., Norman, W., Hammitt, W. E., \& Jodice, L. (2007). A Modified Involvement Scale. Leisure Studies, 26(4), 399-427. https:// doi.org/10.1080/ 02614360600896668

Legault, J. (2017, July 19). The psychological appeal of blockchain technology. Medium. Retrieved from https://medium.com/adventures-in-consumer-tech nology/the-psychologicalappeal-of-blockchain-te chnology-2998a3663775

Macrae, C. N., Moran, J. M., Heatherton, T. F., Banfield, J. F., \& Kelley, W. M. (2004). Medial prefrontal activity predicts memory for self. Cerebral Cortex, 14(6), 647-654. https://doi.org/10.10 93/cercor/bhh025

McAdams, D. P., Josselson, R., \& Lieblich, A. (Eds.). (2006). Identity and story: Creating self in narrative. Washington, D.C.: American Psychological Association.

Moskowitz, G. B. (2005). Social cognition: Understanding self and others. New York, NY: Guilford Press. 
Nisbett, R. E., \& Wilson, T. D. (1977). Telling more than we can know: Verbal reports on mental process. Psychological Review, 84(3), 231-259. https:// doi.org/10.1037/0033-295X.84.3.231

Okazaki, S., David, E. J. R., \& Abelmann, N. (2008). Colonialism and psychology of culture. Social and Personality Psychology Compass, 2(1), 90-106. https://doi.org/10.1111/j.17519004.2007.00046.x

Prayoga, T., \& Abraham, J. (2017). Technopsychology of IoT optimization in the business world. In I. Lee (Ed.), The Internet of Things in the modern business environment (pp. 50-75). Hershey, PA: IGI Global.

Price, M. E. (2013, June 25). Human herding: How people are like guppies. Psychology Today. Retrieved from https://www.psychologytoday.com/us/ blog/darwin-eternity/201306/humanherding-howpeople-are-guppies

Revilla, L. A. (1997). Filipino American identity: Transcending the crisis. In M. P. P. Root (Ed.), Filipino Americans: Transformation and identity (pp. 95-111). Thousand Oaks, CA: Sage. https:// doi.org/10.4135/9781452243177.n7

Snow, C. J., Duval, T. S., \& Sylvia, P. J. (2004). When the self stands out: Figure-ground effects on self-focused attention. Self and Identity, 3(4), 355363. https://doi.org/10.1080/13576500444000128

Symons, C. S., \& Johnson, B. T. (1997). The self- reference effect in memory: A meta-analysis. Psychological Bulletin, 121(3), 371-394. https://doi. org/10.1037/0033-2909.121.3.371

Twenge, J. M., Catanese, K. R., \& Baumeister, R. F. (2003). Social exclusion and the deconstructed state: Time perception, meaninglessness, lethargy, lack of emotion, and self-awareness. Journal of Personality and Social Psychology, 85(3), 409-423. https://doi.org/10.1037/0022-3514.85.3.409

Williams, R. R. (2000). Hegel's ethics of recognition. Berkeley, California, US: University of California Press.

Williams, K. D., Cheung, C. K. T., \& Choi, W. (2000). Cyberostracism: Effects of being ignored over the internet. Journal of Personality and Social Psychology, 79(5), 748-762. https://doi.org/10.10 37/0022-3514.79.5.748

Wu, P. C. (2017). Is the fascination of blockchain illusion or truth? Psychology Today. Retrieved from https://www.psychologytoday.com/us/blog/jacob s-staff/201712/is-the-fascinationblockchain-illusi on-or-truth

Zadro, L., Williams, K. D., \& Richardson, R. (2004). How low can you go? Ostracism by a computer is sufficient to lower self-reported levels of belonging, control, self-esteem, and meaningful existence. Journal of Experimental Social Psychology, 40(4), 560567. https://doi.org/10.1016/j.jesp.2003.11.006 